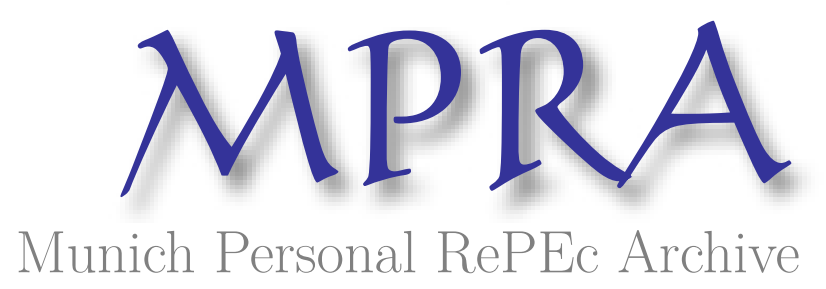

\title{
Liberating Supply: Fiscal Policy and Technological Innovation in a Multicountry Model
}

Bayoumi, Tamim and Coe, David T. and Laxton, Douglas

International Monetary Fund

June 1998

Online at https://mpra.ub.uni-muenchen.de/8596/

MPRA Paper No. 8596, posted 07 May 2008 14:44 UTC 


\section{IMF Working Paper}

(C) 1998 International Monetary Fund
This is a Working Paper and the author(s) would welcome any comments on the present text. Citations should refer to a Working Paper of the International Monetary Fund. The views expressed are those of the author(s) and do not necessarily represent those of the Fund.

WP/98/95

INTERNATIONAL MONETARY FUND

African, Asia and Pacific, and Research Departments

\title{
Liberating Supply: Fiscal Policy and Technological Innovation in a Multicountry Model ${ }^{1}$
}

Prepared by Tamim Bayoumi, David T. Coe, and Douglas Laxton

June 1998

\begin{abstract}
This paper examines how endogenizing technological progress in a multicountry macroeconometric model affects the analysis of fiscal policies. It uses an expanded version of the IMF's multicountry model, MULTIMOD, in which total factor productivity (TFP) is endogenized as a function of domestic research and development (R\&D) expenditures, R\&D expenditures of trading partners, and trade. Compared with the standard version of the model with exogenous TFP, fiscal policies have much larger and long-lived effects on the domestic economy and on other countries.
\end{abstract}

JEL Classification Numbers: O31, 040

Keywords: Technological Progress, R\&D, Econometric Models

Authors’ E-Mail Address: tbayoumi@imf.org, dcoe@imf.org, dlaxton@imf.org

${ }^{1}$ This paper was presented at the Royal Economic Society Annual Conference University of Warwick (1 April 1998). We thank Paul Masson and Peter Isard for their comments, and Susanna Mursula and Dirk Muir for research assistance. 


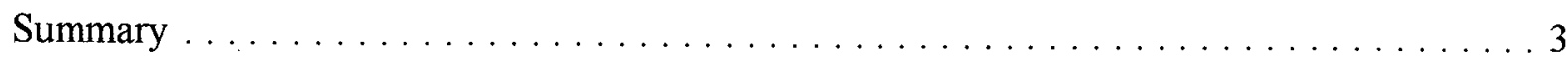

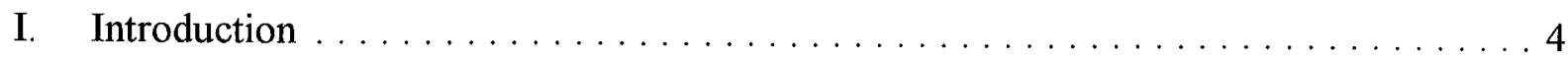

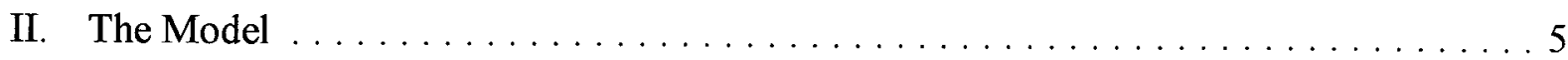

III. Simulation Results $\ldots \ldots \ldots \ldots \ldots \ldots \ldots \ldots \ldots \ldots \ldots \ldots \ldots$

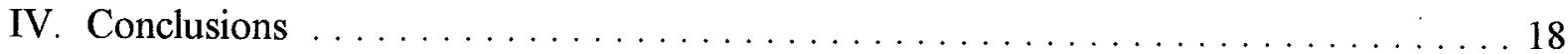

Appendix I: Summary of MULTIMOD Mark III $\ldots \ldots \ldots \ldots \ldots \ldots \ldots \ldots \ldots \ldots \ldots$

References . . . . . . . . . . . . . . . . . . . . . . 24

Tables

1. Effects of Higher Government Expenditures and Larger Government Debt

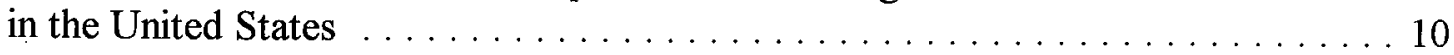

2. Effects of Higher Government Expenditures and Larger Government Debt

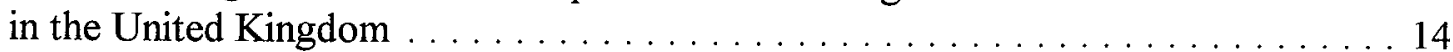

3. Effects of a Temporary Tax Cut and Permanently Larger Government Debt

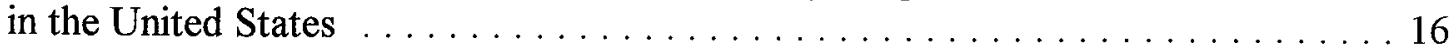

4. Effects of a Temporary Tax Cut and Permanently Larger Government Debt in the United Kingdom . . . . . . . . . . . . . . . . . . . . . . . . . . . . . . . 19

Figures

1. Effects of Higher Government Expenditures and Larger Government Debt

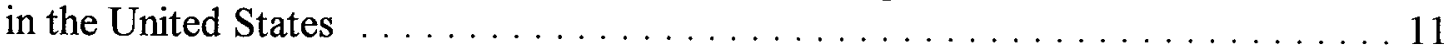

2. Effects of Higher Government Expenditures and Larger Government Debt in the United Kingdom . . . . . . . . . . . . . . . . . . . . . . . 15

3. Effects of a Temporary Tax Cut and Permanently Larger Government Debt in the United States . . . . . . . . . . . . . . . . . . . . . . . . . . 17

4. Effects of a Temporary Tax Cut and Permanently Larger Government Debt in the United Kingdom . . . . . . . . . . . . . . . . . . . . 20 


\section{Summary}

This paper looks at the consequences of endogenizing technological innovation for the analysis of fiscal policies. Macroeconomic policy analyses rarely consider the supply side of the economy in detail, concentrating instead on cyclical factors. Yet research and development (R\&D) expenditures are important determinants of innovation, technological progress, and economic growth. By incorporating recent empirical work on the relationship between R\&D spending and technological progress into a large macroeconomic model, this paper looks at some of the consequences of liberating the supply side of the economy for the analysis of fiscal policy.

The results indicate that endogenizing total factor productivity magnifies the long-run effects of fiscal policies on the level of real GDP and stretches out the short- to medium-run effects on economic growth. In particular, the paper finds that incorporating R\&D-induced innovation into the analysis more than doubles the long-run welfare losses associated with higher government spending or temporary tax cuts and reduces real growth for a very long time. To put it somewhat differently, endogenizing $R \& D$ raises the long-run pain of adventurist fiscal policies without providing any extra gain. Furthermore, these costs spill over onto trading partners, because lower levels of technological innovation in any one country hurt the rest of the world through lower demand for their products and through reduced technological spillovers. Indeed, the welfare costs for the rest of the world also approximately double when R\&D is included in the model.

Several lessons can be drawn from this exercise. First, supply-side considerations can dramatically increase the costs of inappropriate policy actions, both in the short run and in the long run. Second, these increased costs are borne across the world, not simply in the country implementing the policies. The international nature of these supply-side costs strengthens the case for international cooperation and surveillance. 


\section{INTRODUCTION}

Profit-maximizing enterprises invest in research and development (R\&D) to develop new products or to increase the efficiency with which they produce and market existing products. For the economy as a whole, R\&D expenditures boost technological progress and economic growth. Aggregate investment in R\&D, like business investment in physical capital, will depend, in part, on current and expected government policies. Economic policies in one country will have an impact on economic developments in their neighbors since national economies are embedded in a global system characterized by mutual interdependence. This interdependence is also reflected in technology transfers between countries as they learn from each other manufacturing methods, modes of organization, marketing, and product design.

Macroeconomic models typically have a very rudimentary supply side, with technological progress - as measured by total factor productivity (TFP)-exogenous, implying that the long-run growth of potential output is also exogenous. In this paper, we liberate supply by making technological progress endogenous and we examine how this affects the empirical analysis of fiscal policies. We use an augmented version of the IMF's multicountry econometric model (MULTIMOD) in which total factor productivity is endogenously dependent on domestic R\&D expenditures, technology transfers from trading partners, and trade. ${ }^{2} \mathrm{R} \& \mathrm{D}$ expenditures are endogenized in a very simple way by keeping them stable relative to GDP. The augmented model is then used to simulate changes in fiscal policies, with particular emphasis on the interactions between economies, and the results are compared with those obtained from the standard version of MULTIMOD.

Our simulations suggest that the interplay between fiscal policies and R\&D expenditures - and thereby between fiscal policies and technological development and technology transfers - is important. Compared with the standard version of the model with exogenous TFP, fiscal policies have much larger effects on the domestic economy and on other countries when TFP is endogenous. In both versions of the model, fiscal policies that result in permanently higher levels of government debt only change the level of GDP in the long run. In the R\&D-augmented version of the model, however, the transition to the steady state takes a very long time, and, hence, the impact on economic growth is very long-lived.

We outline in the next section the theoretical framework and key empirical features of MULTIMOD, as well as the theoretical considerations that have guided the specification of the total factor productivity equations incorporated into the model. A summary of the Mark III version of MULTIMOD that we use is given in an appendix. In Section III we discuss the simulation results. Section IV concludes.

\footnotetext{
${ }^{2}$ This paper complements and extends Bayoumi, Coe, and Helpman (1998), who use a similar augmented model based on an earlier version of MULTIMOD to look at the impact of increases in $R \& D$ expenditures in industrial countries, including the spillover effects to other industrial countries and to four developing country regions.
} 


\section{The ModeL}

Our version of MULTIMOD consists of linked econometric models for each of the G7 countries and an aggregate model for a grouping of 14 smaller industrial countries. ${ }^{3}$ The most important theoretical and empirical features of these models are summarized below to help understand the simulation results presented in the next section.

MULTIMOD is non-Ricardian; hence, changes in the level of world government debt will cause an increase in the level of real interest rates and a reduction in world saving and investment. Following Blanchard (1985), it is assumed that the representative individual in each country faces a constant probability of death and has access to perfect annuity markets. Because some individuals are assumed to be liquidity constrained in the short run, real consumption depends partly on changes in current real disposable income and on real longterm interest rates in addition to wealth. Aggregate saving is derived from consumption, and the world real interest rate adjusts to equilibrate world saving and investment. Long-term interest rates, are determined by the expectations theory of the term structure, implying that they are a moving average of current and expected future short-term rates. Financial assets of the industrial countries are assumed to be perfect substitutes, and nominal exchange rates are determined by an interest parity equation.

The theoretical structure that drives MULTIMOD's long-run supply behavior is neoclassical: output is determined a Cobb-Douglas production function in the long run and by aggregate demand in the short run. Investment is modeled as a gradual adjustment of the capital stock toward its optimal level, which is determined by the gap between the market value of the existing stock and its replacement cost, following Tobin (1969). Although in each country investment need not equal savings, because the gap can be financed by international capital flows, the intertemporal budget constraints imply that the long-run growth of the capital stock is determined by the growth of labor and the growth of TFP. In the long run, the growth of output is also determined by the same factors, and the capital-output ratio is constant. An implication of these relationships is that the long-run growth rate of per capita output is entirely determined by the growth rate of TFP. These features are familiar from the neoclassical growth models of Solow (1956) and Cass (1965).

Potential output is determined by capital, full-employment labor input, and TFP, which is exogenous in the standard version of the model. This supply side is augmented by short-run dynamics emanating largely from changes in aggregate demand caused by the interaction between sticky prices and backward-looking expectations. While changes in aggregate demand move actual output temporarily away from potential output, the equilibrium values of real variables will be unaffected by level shocks to the money supply. However, government

${ }^{3}$ MULTIMOD Mark III also contains aggregate models for developing countries and for transition countries. A detailed description of MULTIMOD Mark III is presented in Laxton and others (1998). See also Bayoumi, Coe, and Helpman (1998), and Masson, Symansky, and Meredith (1990). 
debt has a long-run impact, reflecting a positive birth rate (see Weil (1989) and Buiter (1988)). Because the Mark III version has well-defined steady state properties, it is well suited to studying fiscal policy issues that involve trade-offs between short-run benefits and long-run costs. MULTIMOD also features model-consistent expectations in goods, financial, and labor markets. The forward-looking aspect of the model means that changes in expectations of future increases in productivity or wealth can have immediate effects on, for example, current consumption and investment.

We augment the standard version of MULTIMOD with equations that relate TFP to R\&D investment, R\&D spillovers from trading partners, and trade. In doing so, total factor productivity becomes endogenous, as suggested by the new growth theory (see Romer (1990), Grossman and Helpman (1991), and Aghion and Howitt (1992)). Although we do not endogenize $R \& D$ investment as a function of economic factors, we make it partially endogenous by keeping the ratio of R\&D investment to GDP unchanged from the baseline in the simulations.

The theoretical basis for our modeling of total factor productivity is provided by Grossman and Helpman (1991, chapter 5). In this model, TFP depends on the available assortment of intermediate inputs. These intermediates can be either horizontally differentiated as different types of inputs or vertically differentiated in quality ladders. The more intermediates are used in production, the higher is TFP. New intermediate inputs are created through R\&D undertaken by profit-seeking enterprises, implying that the total number of available intermediates is a function of past $R \& D$ investment. It is important to note that our model incorporates diminishing returns to the reproducible factors of production (physical and R\&D capital) in aggregate. ${ }^{4}$ This implies that a permanent increase in R\&D investment will have a level effect on output, but will not permanently raise the rate of growth of output. It takes a very long time, however, to approach the new steady state, and, hence, the impact on economic growth is very long-lived (see Bayoumi, Coe, and Helpman (1998)).

We endogenize industrial country TFP based on the estimation results in Coe and Helpman (1995). ${ }^{5}$ TFP is determined by both domestic R\&D capital $\left(S^{D}\right)$ and foreign R\&D capital $\left(S^{F}\right)$. Trade is assumed to be the vehicle for R\&D spillovers; thus, foreign R\&D capital,

\footnotetext{
${ }^{4}$ That is to say, it is not an "AK" model; see, for example, Romer (1990).

${ }^{5}$ The equations reported in Coe and Helpman (1995) (CH) have been modified in light of Lichtenberg and van Pottelsberghe de la Potterie (1998), who point out that the CH estimates of the elasticity of TFP with respect to the foreign R\&D capital stock are sensitive to the normalization of the foreign R\&D capital stock series, which was indexed to equal 1.0 in 1985. For this reason we have reestimated the $\mathrm{CH}$ equations, using the unindexed data on foreign R\&D capital stocks and adding the import share as an independent variable (the import share was omitted in the CH specification because the estimated coefficient was insignificant). This modification has only a small effect on the estimated elasticity of TFP with respect to the foreign $R \& D$ capital stock (the new elasticity is 0.26 , compared with 0.29 in $\mathrm{CH})$. We report the corrected estimates in the text below and use them in the simulations.
} 
which is defined below, affects TFP through its interaction with the import share $(m)$. The equation determining TFP $(F)$ for each of the G-7 countries is

$$
\log F=\phi_{1}+0.24 \log S^{D}+0.26 m \cdot \log S^{F}-3.18 m
$$

where $\phi_{1}$ is a country-specific constant. For the small industrial countries in aggregate, TFP is determined in the same manner; except that domestic $R \& D$ capital has a smaller impact, which may reflect that they perform $R \& D$ across a narrower range of $R \& D$ activities:

$$
\log F=\phi_{2}+0.08 \log S^{D}+0.26 \mathrm{~m} \cdot \log S^{F}-3.18 m
$$

Although the specification of our TFP equations focus on the role of R\&D and trade, there clearly are other important determinants of TFP such as improvements in human capital and infrastructure investment. ${ }^{6}$

The simulation results reported in the next section will, of course, depend importantly on the size of the estimated parameters in these equations. The elasticity of TFP with respect to domestic R\&D capital $\left(S^{D}\right)$ is within the range of results from the studies surveyed by Nadiri (1993) and, at least for the small industrial countries, by Griliches (1988). The foreign R\&D capital stock $\left(S^{F}\right)$ and the import share $(m)$ interacted with each other in the equations, so their elasticities will depend on the level of the other variable. Given an average value of the import share $(m)$ of about 0.3 , the elasticity of total factor productivity with respect to foreign R\&D capital is $0.08 .{ }^{7}$ This estimate is, if anything, at the low end of the range of results from the studies of R\&D spillovers or externalities surveyed by Nadiri (1993) and Mohnen (1994). ${ }^{8}$

The domestic R\&D capital stocks of the G-7 industrial countries and the small industrial countries in aggregate consist of their cumulative real investment in R\&D, allowing for a depreciation rate of 5 percent. The foreign $R \& D$ capital stock for each country is a weighted average of its industrial country trading-partners' domestic R\&D capital stocks, using bilateral import shares as weights. ${ }^{9}$

${ }^{6}$ Coe, Helpman, and Hoffmaister (1997) include a proxy for human capital, in addition to R\&D spillovers and trade, as a determinant of TFP in developing countries.

${ }^{7}$ Although the coefficient on the import share by itself is negative, given an average value of the logarithm of foreign R\&D capital of about 12, the "total" elasticity of TFP with respect to the import share is roughly zero.

${ }^{8}$ See also Eaton and Kortum (1996), who find large and significant international technology spillovers based on patent data.

${ }^{9}$ Keller (1998) has argued, based on a Monte Carlo study, that weights based on random import shares perform as well as bilateral import shares. As shown in Bayoumi, Coe, and 


\section{Simulation Results}

We focus on fiscal policy simulations that result in a permanent rise in government debt. One result of increasing international financial integration has been an expansion of the markets in which governments can sell their debt. In principle, this expansion allows governments greater scope to smooth taxation and spending (and individuals greater scope to smooth consumption) in the face of temporary shocks. But increasing capital market integration also implies that the fiscal policies of one country will have greater spillover effects on other countries. In particular, in a world with highly integrated capital markets and consumers who do not fully offset the reduction in national saving caused by government deficits, a country that issues a large amount of debt will raise real interest rates throughout the world and crowd out private investment in all countries. ${ }^{10}$ As such, these deficits reduce both national and world saving, resulting in a smaller world capital stock, and, in the medium term, a lower level of per capita real income and consumption.

We report two fiscal policy simulations: a permanent increase in government expenditure, with tax rates varying to achieve a prespecified rise in the level of government debt relative to GDP; and a temporary tax cut, with real government expenditure unchanged relative to potential GDP, resulting in a permanent rise in government debt. In order to assess the empirical significance for policy analysis of endogenizing long-run supply, each simulation is conducted on both the standard and the R\&D-augmented versions of MULTIMOD. The simulations are reported for the United States and the United Kingdom, in part to illustrate how the size of the country affects the magnitude of spillovers to other countries.

We mainly focus on the medium and long run. The short-run effects of fiscal policy depend on the initial state of the economy, through the nonlinear Phillips curve, and the monetary response. ${ }^{11}$ The simulations assume that the money supply is kept fixed along its

${ }^{9}$ (...continued)

Helpman (1998), if the foreign R\&D capital is constructed as an unweighted average of the domestic R\&D stocks of trading partners, which is similar to the weights used by Keller, the simulation results are broadly unchanged except for the distribution of spillovers among trading partners.

${ }^{10}$ Recent empirical evidence of significant effects of world government debt on real interest rates is presented in Tanzi and Fanizza (1995) and Ford and Laxton (1995).

${ }^{11}$ The baseline for the simulations is constructed from the projections to the year 2002 in the IMF's (1997) World Economic Outlook, by this time, unemployment is assumed equal to the natural rate, and actual output is assumed to be equal to potential. After 2002, employment and output remain in equilibrium as each country in the model slowly moves to a full stockflow equilibrium, in which some countries are net debtors and others are net creditors.

Because the model has forward-looking behavior, it is necessary to specify terminal conditions for the simulations; these conditions are obtained from the steady state analog model that is 
baseline target path, and the short-run responses are sensitive to this assumption. ${ }^{12}$ In the long run, however, this assumption has no impact on real variables.

Before discussing the simulations, we need to address the accounting issue of where R\&D expenditures fit into the model. In the early 1990s, about 50 percent of business sector R\&D expenditures were labor costs, 40 percent were other current expenditures, and 10 percent were capital expenditures. ${ }^{13}$ In the simulations discussed below, any change in R\&D expenditures is assumed to be reflected in business consumption-an element of aggregate demand introduced into the model for these simulations - and financed out of current and future business profits. This assumption implies that an enterprise would have to forgo fixed investment in order to increase R\&D expenditures.

The first set of simulations is summarized in Table 1 and Figure 1. The simulations consist of a permanent increase in U.S. real government expenditure of 2 percent of baseline real GDP. The rise in government spending is assumed to be for goods and services that have no potential impact on total factor productivity, thus excluding, for example, higher spending on education, infrastructure, or government research. Tax rates remain unchanged for the first five years of the simulation, resulting in an increase in the debt-to-GDP ratio of approximately 10 percentage points. After the fifth year, the fiscal authorities are assumed to adjust the tax rate to hold the debt-to-GDP ratio constant at a level that is 10 percentage points higher than in the baseline.$^{14}$ We consider first the simulation results based on the standard version of the model with exogenous TFP (the second column in Table 1 and the dashed lines in Figure 1).

The rise in U.S. government spending increases the fiscal deficit and boosts output and interest rates in the short run, which, together with an appreciation of the U.S. dollar, "crowd out" private consumption, investment, and net exports. The fall in national (private plus public) saving tends to worsen the current account balance and increase the level of net

\footnotetext{
${ }^{11}($...continued $)$

embedded in the Mark III version of MULTIMOD.
}

${ }^{12}$ Laxton and others (1998) illustrate how the short-run effects of fiscal shocks depend on the reactions of the monetary authorities.

${ }^{13}$ These estimates are from OECD (1995a) and refer to the average of the G-7 countries other than the United States (for which a breakdown is not available). Only R\&D capital expenditures would be included directly as an element of aggregate demand in the national accounts, although these represented less than 1 percent of business fixed investment. Other $\mathrm{R} \& \mathrm{D}$ expenditures would affect aggregate demand indirectly through their effects on incomes and production.

${ }^{14}$ MULTIMOD Mark III version contains distortionary capital taxes, as well as nondistortionary labor taxes. In the fiscal experiments reported here, the tax rate on capital income is unchanged. 
Table 1. Effects of Higher Government Expenditures and Larger Government Debt in the United States

(Deviations from baseline as a percent of baseline, unless otherwise indicated.)

\begin{tabular}{|c|c|c|c|}
\hline GDP & Endogenous TFP & Exogenous TFP & Difference \\
\hline \multicolumn{4}{|l|}{ United States } \\
\hline Year 1 & 0.77 & 0.72 & 0.05 \\
\hline Year 5 & -0.01 & -0.17 & 0.16 \\
\hline Steady state & -1.25 & -0.41 & -0.84 \\
\hline Net present value ${ }^{1}$ & -32.82 & -17.11 & -15.71 \\
\hline \multicolumn{4}{|l|}{ Other industrial countries } \\
\hline Year 1 & 0.24 & 0.32 & -0.08 \\
\hline Year 5 & -0.39 & -0.16 & -0.23 \\
\hline Steady state & -0.80 & -0.54 & -0.26 \\
\hline Net present value $^{1}$ & -25.39 & -18.02 & -7.36 \\
\hline \multicolumn{4}{|l|}{ Private consumption } \\
\hline \multicolumn{4}{|l|}{ United States } \\
\hline Year 1 & -1.27 & -1.27 & -0.00 \\
\hline Year 5 & -1.66 & -1.72 & 0.06 \\
\hline Steady state & -4.50 & -3.56 & -0.93 \\
\hline Net present value ${ }^{1}$ & -170.82 & -152.83 & -17.99 \\
\hline NPV of private plus & & & \\
\hline government consumption ${ }^{2}$ & -36.14 & -18.15 & -17.99 \\
\hline \multicolumn{4}{|l|}{ Other industrial countries } \\
\hline Year 1 & 0.28 & 0.39 & -0.11 \\
\hline Year 5 & -0.44 & -0.20 & -0.24 \\
\hline Steady state & -0.60 & -0.25 & -0.35 \\
\hline Net present value ${ }^{1}$ & -19.89 & -9.50 & -10.39 \\
\hline
\end{tabular}

${ }^{1}$ The net present value for each variable assumes a discount rate of 4.2 percent and is expressed as a percent of the baseline value in the first year of the simulation.

${ }^{2}$ Expressed as a percent of the baseline value of private consumption in the first year of the simulation. 


\section{Figure 1: Effects of Higher Government Expenditures and Larger Government Debt in the United States}

Deviations from baseline as a percent of the baseline
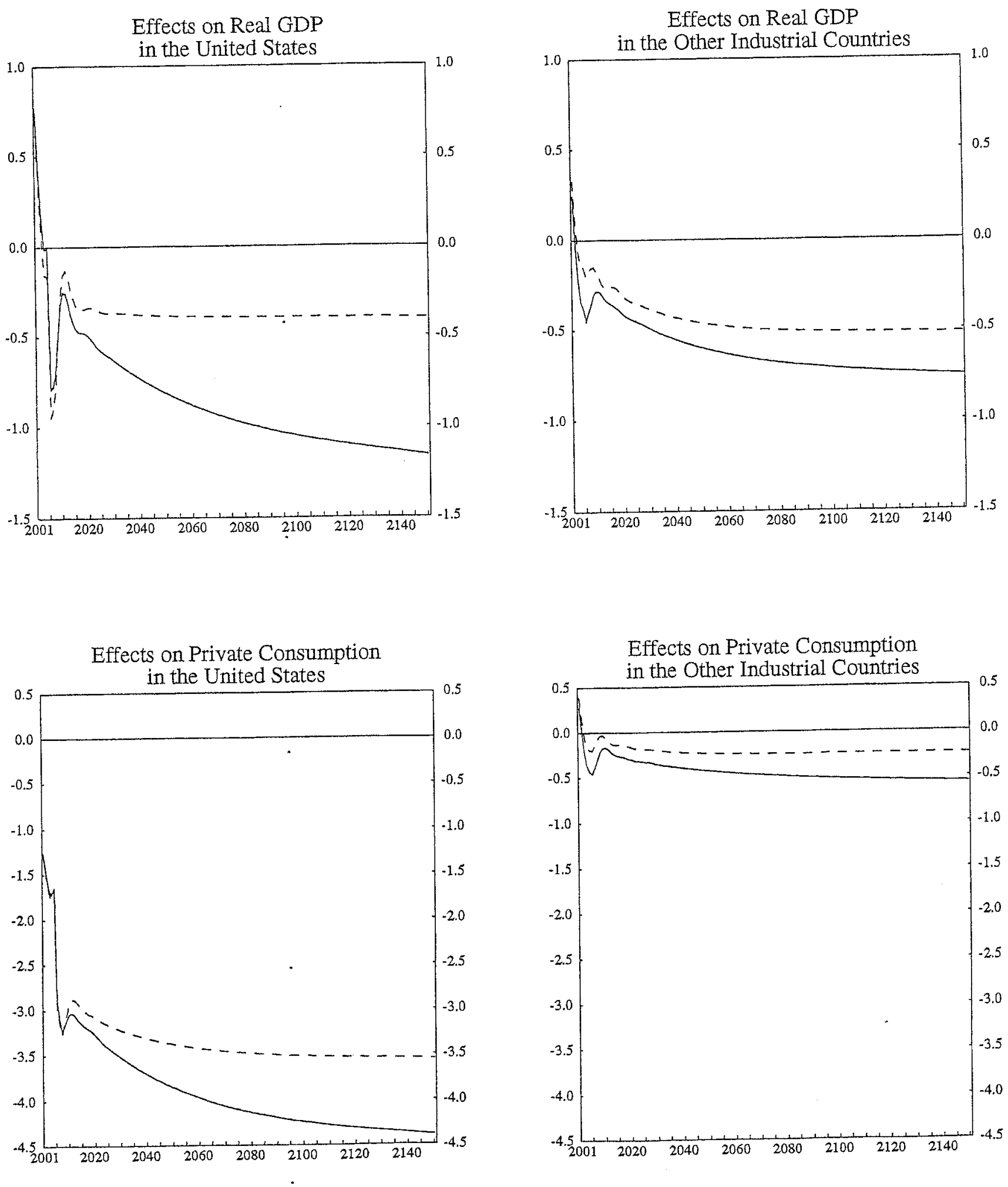
foreign liabilities; in order to finance the higher interest payments to foreigners, net exports rise in the steady state, in association with a permanent decline in real competitiveness. In the long run, the level of private consumption and disposable income are lower because of the permanent increase in the aggregate tax burden needed to finance the rise in expenditure and the higher interest payments on the larger stock of public debt, and because a smaller capital stock and higher net foreign liabilities shrink the consumption-possibilities frontier of the economy. The decline in the level of real GDP is considerably less than the fall in real consumption, reflecting the positive contributions to GDP from real government spending and real net exports. The medium-run dynamics are largely played out after about 20 years, and the growth of real GDP is essentially the same as in the baseline thereafter.

The effects on other industrial countries are broadly similar to the domestic impact in the United States. The main differences are that (i) the initial rise in output is somewhat smaller, (ii) consumption rises rather than falls in the first year reflecting a temporary increase in real disposable income, and (iii) the long-run decline in the level of consumption is smaller than the decline in the level of GDP, reflecting the fall in investment and net exports (and no change in real government spending).

These simulation results are fairly standard from multicountry models with nonRicardian features (see McKibbin and Sachs (1991)). The main transmission mechanism is the rise in the domestic and the world real interest rates which restrains business investment and reduce income and consumption in both the domestic economy and in other economies.

When TFP is endogenized, an additional transmission mechanism that magnifies and extends the long-term negative effects of higher government expenditures while leaving the short-term multipliers largely unchanged, as shown in the first column of Table 1 and the solid lines in Figure 1. The long-run decline in real GDP and investment is amplified because it is accompanied by a fall in $R \& D$ expenditure, which feeds through into a smaller $R \& D$ capital stock and lower TFP. There is also a feedback effect as the slower future technological progress further reduces investment and output: the dynamic interaction between lower output and reduced $\mathrm{R} \& \mathrm{D}$ accounts for about one-third of the additional long-run decline in real GDP in the R\&D-augmented model compared with the standard model. Moreover, the decline in the U.S. R\&D capital stock implies a fall in the foreign R\&D capital stocks of other countries-and, hence, a decline in their TFP-which enlarges the negative spillover effects from the standard model.

In the model with endogenous TFP, the steady state decline in real GDP in the United States is three times as great as in the standard model, while the negative impact on output in other countries is [In Table 1] almost 50 percent larger. Welfare also falls significantly. The net present value of total U.S. consumption (private plus public) declines by 36 percent from the baseline level of private consumption in the first year of the simulation, compared with 18 percent in the standard model; the decline in welfare is, of course, considerably greater if 
the increase in government expenditure is assumed to have no impact on private welfare ${ }^{15}$ The decline in the net present value of total consumption in other countries is also about twice as large as in the standard model.

The transition to the new steady state is considerably longer in the model with endogenous TFP, as economic growth is lower than in the baseline for the full 150 years shown in Figure 1. Some of the elongation of the response comes from the interaction of two stock accumulation processes, for physical investment and R\&D. However, our assumption that $R \& D$ responds to changes in GDP also has some effect. If $R \& D$ spending were made more forward looking by modeling it in a similar manner to physical investment, it would respond more rapidly to the change in fiscal policy, and the model would reach the steady state faster. This would imply a larger short- to medium-term impact on growth in the simulation with endogenous $R \& D$, and concomitantly larger welfare losses.

This simulation shows that endogenizing TFP magnifies the negative impact of fiscal adventurism on both the United States and the rest of the world because of the slower pace of innovation in the United States and the corresponding reduction of technological spillovers to trading partners.

A simulation of a comparable permanent increase in U.K. government expenditures of 2 percent of baseline GDP is presented in Table 2 and Figure 2. The spillover effects on other countries are somewhat smaller, but otherwise the results are broadly similar to those of the U.S. simulation. The spillover effects on other countries are smaller because an increase in government debt in the United Kingdom has a smaller effect on world saving and therefore results in a smaller increase in the world real interest rate. Compared with the standard model, the medium- to long-run effects of fiscal policies are again magnified in the R\&D-augmented model. It is noteworthy, that if the increase in government spending is assumed to have a positive impact on welfare, the standard version of the model indicates that the net present value of public plus private consumption rises by almost 3 percent from the initial level of public plus private consumption, implying that the higher level of government expenditure improves aggregate economic welfare. R\&D-augmented version of the model, by contrast, the net present value of total consumption declines by 17 percent, implying that the higher level of government expenditure reduces aggregate economic welfare.

The second type of fiscal shock, presented in Table 3 and Figure 3 , is a pure debt shock in the United States of 10 percentage points, in which the aggregate tax rate is reduced by 2 percentage points for five years and then allowed to increase to finance the interest payments on the higher level of government debt. This shock represents the tax-cut version of the earlier simulation in which government expenditure was raised. As the model is non-Ricardian, tax cuts boost private sector activity temporarily, but the long-term impact of larger debt is negative, both in the home country and abroad. In the conventional version of

\footnotetext{
${ }^{15}$ These calculations assume a discount rate of 4.2 percent which is equal to the equilibrium real interest rate on government debt and is greater than the growth rate of potential output in the baseline, a necessary condition to rule out Ponzi games.
} 
Table 2. Effects of Higher Government Expenditures and Larger Government Debt in the United Kingdom

(Deviations from baseline as a percent of baseline, unless otherwise indicated.)

\begin{tabular}{|c|c|c|c|}
\hline GDP & Endogenous TFP & Exogenous TFP & Difference \\
\hline \multicolumn{4}{|l|}{ United Kingdom } \\
\hline Year 1 & 1.49 & 1.11 & 0.38 \\
\hline Year 5 & 0.94 & -0.29 & 1.23 \\
\hline Steady state & -1.36 & -0.13 & -1.23 \\
\hline Net present value ${ }^{1}$ & -25.02 & -6.79 & -18.23 \\
\hline \multicolumn{4}{|l|}{ Other industrial countries } \\
\hline Year 1 & 0.04 & 0.07 & -0.03 \\
\hline Year 5 & -0.09 & -0.01 & -0.08 \\
\hline Steady state & -0.28 & -0.09 & -0.19 \\
\hline Net present value $^{1}$ & -7.53 & -3.41 & -4.12 \\
\hline \multicolumn{4}{|l|}{ Private consumption } \\
\hline \multicolumn{4}{|l|}{ United Kingdom } \\
\hline Year 1 & 0.99 & 0.82 & 0.18 \\
\hline Year 5 & 0.76 & 0.02 & 0.74 \\
\hline Steady state & -4.90 & -3.59 & -1.32 \\
\hline Net present value ${ }^{1}$ & -159.52 & -139.48 & -20.04 \\
\hline \multicolumn{4}{|l|}{ NPV of private plus } \\
\hline government consumption ${ }^{2}$ & -17.39 & 2.65 & -20.04 \\
\hline \multicolumn{4}{|l|}{ Other industrial countries } \\
\hline Year 1 & -0.02 & 0.01 & -0.03 \\
\hline Year 5 & -0.15 & -0.08 & -0.07 \\
\hline Steady state & -0.29 & -0.06 & -0.23 \\
\hline Net present value ${ }^{1}$ & -8.15 & -2.83 & -5.32 \\
\hline
\end{tabular}

${ }^{1}$ The net present value for each variable assumes a discount rate of 4.2 percent and is expressed as a percent of the baseline value in the first year of the simulation.

${ }^{2}$ Expressed as a percent of the baseline value of private consumption in the first year of the simulation. 
Figure 2: Effects of Higher Government Expenditures and Larger Government Debt in the United Kingdom

Deviations from baseline as a percent of the baseline Mark III: Endogenous TFP

- - Mark III: Exogenous TFP

Effects on Real GDP

in the United Kingdom

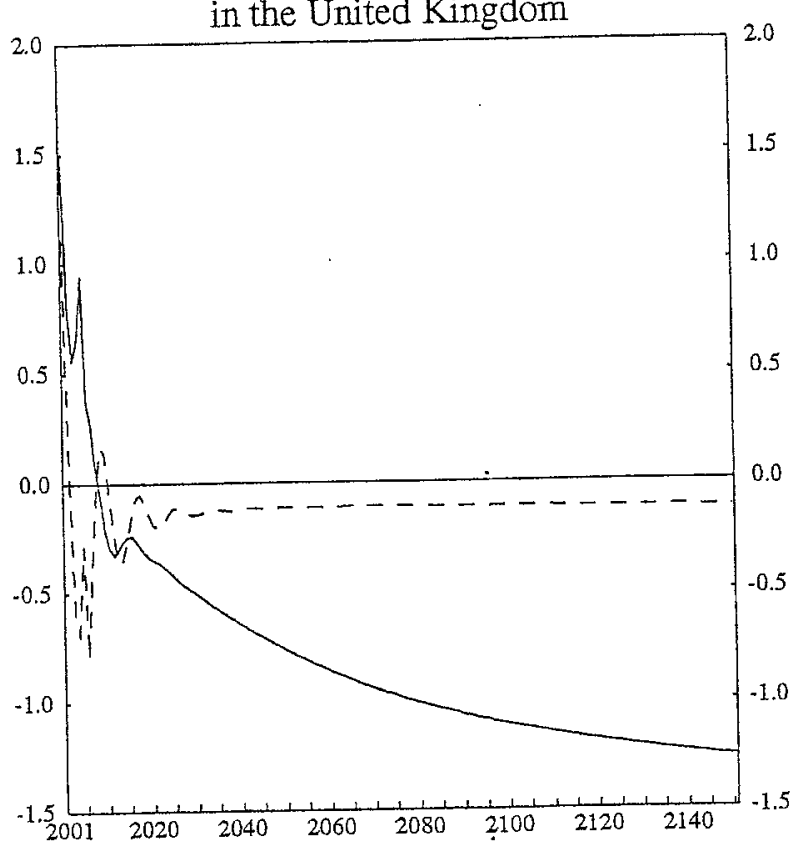

Effects on Private Consumption in the United Kingdom

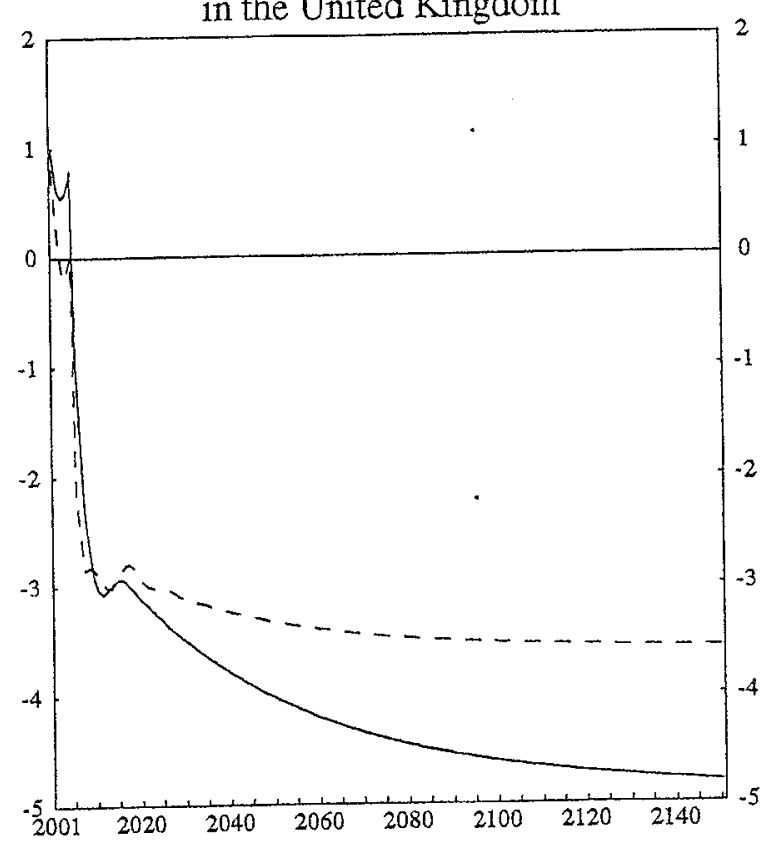

Effects on Real GDP

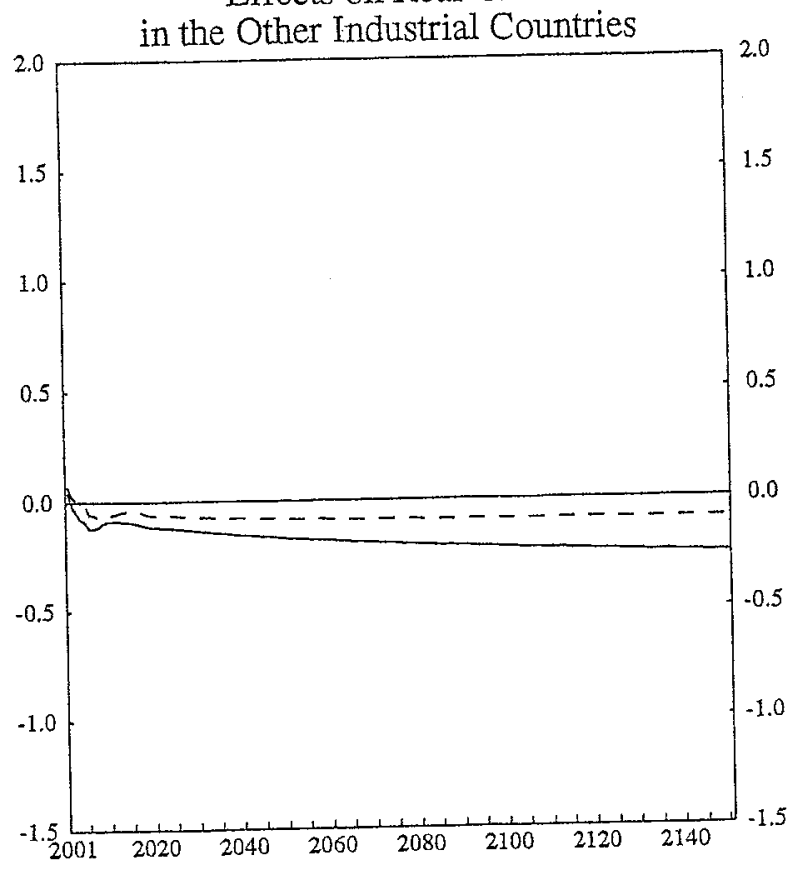

Effects on Private Consumption in the Other Industrial Countries

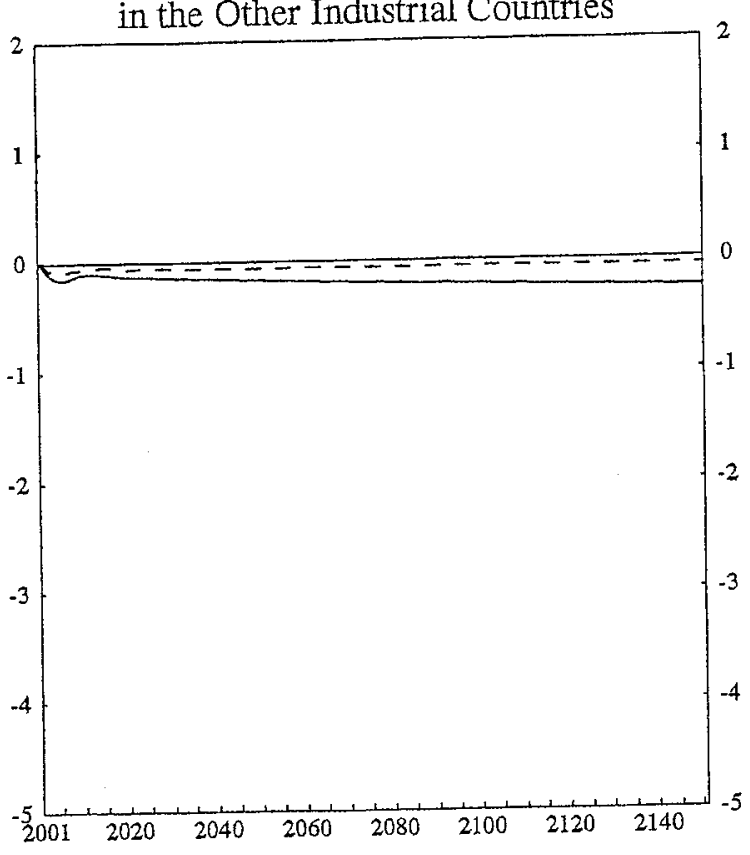


Table 3. Effects of a Temporary Tax Cut and Permanently Larger Government Debt in the United States

(Deviations from baseline as a percent of baseline, unless otherwise indicated.)

\begin{tabular}{|c|c|c|c|}
\hline \multicolumn{4}{|c|}{ - } \\
\hline \multicolumn{4}{|l|}{ United States } \\
\hline Year 1 & 0.71 & 0.65 & 0.06 \\
\hline Year 5 & 0.04 & -0.13 & 0.17 \\
\hline Steady state & -0.96 & -0.34 & -0.62 \\
\hline Net present value ${ }^{1}$ & -25.88 & -14.66 & -11.22 \\
\hline \multicolumn{4}{|c|}{ Other industrial countries } \\
\hline Year 1 & 0.23 & 0.30 & -0.07 \\
\hline Year 5 & -0.34 & -0.14 & -0.20 \\
\hline Steady state & -0.61 & -0.43 & -0.18 \\
\hline Net present value ${ }^{1}$ & -20.40 & -15.13 & -5.27 \\
\hline \multicolumn{4}{|l|}{ Private consumption } \\
\hline \multicolumn{4}{|l|}{ United States } \\
\hline Year 1 & 1.32 & 1.29 & 0.03 \\
\hline Year 5 & 1.06 & 0.96 & 0.09 \\
\hline Steady state & -1.36 & -0.68 & -0.68 \\
\hline Net present value ${ }^{1}$ & -28.96 & -16.18 & -12.78 \\
\hline \multicolumn{4}{|c|}{ Other industrial countries } \\
\hline Year 1 & 0.26 & 0.35 & -0.09 \\
\hline Year 5 & -0.38 & -0.18 & -0.20 \\
\hline Steady state & -0.43 & -0.19 & -0.24 \\
\hline Net present value $^{1}$ & -15.10 & -7.64 & -7.47 \\
\hline
\end{tabular}

${ }^{1}$ The net present value for each variable assumes a discount rate of 4.2 percent and is expressed as a percent of the baseline value in the first year of the simulation. 
Figure 3: Effects of a Temporary Tax Cut and Permanently Larger Government Debt in the United States

Deviations from baseline as a percent of the baseline Mark II: Endogenous TFP - - Mark III: Exogenous TFP
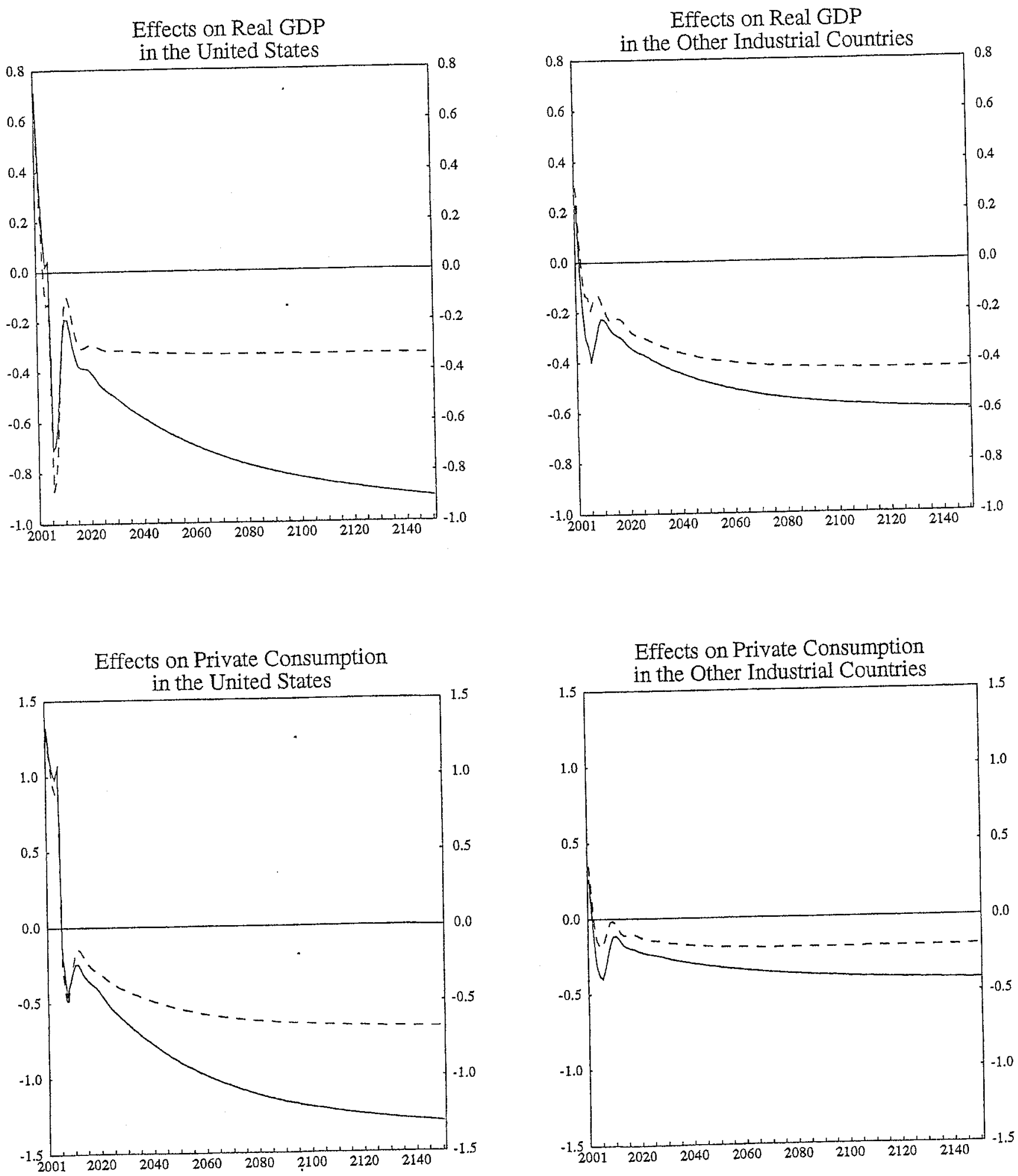
MULTIMOD both the short-term boost to activity and the subsequent fall in GDP are smaller than in the previous simulation of higher government spending. The short-term boost to activity is smaller because some of the high income is saved, while the long-term fall comes from the fact that less private sector investment is crowded out.

The results from the $R \& D$-augmented model again indicate that the decline in $R \& D$ spending expands the long-term losses from fiscal adventurism without enhancing the shortterm benefits. The reduction in U.S. R\&D investment that goes hand in hand with the fall in business investment magnifies the long-run decline in U.S. GDP by a factor of almost three, and increases the drop in GDP in other countries by 50 percent, compared to the standard model. The detrimental impact on welfare is also magnified.

A simulation of a comparable tax cut in the United Kingdom gives results that are broadly similar to but smaller than the U.S. simulation results, as shown in Table 4 and Figure 4. Compared with the simulation of higher U.K. government expenditure, the domestic effects of a U.K. tax cut are considerably smaller, as was the case in the U.S. simulations. With endogenous TFP, the long-run impact on GDP and consumption is again magnified and longer lasting than with the standard model.

\section{ConcLusions}

This paper has looked at the consequences of endogenizing technological innovation for the analysis of fiscal policies. Macroeconomic policy analyses rarely consider the supply side of the economy in detail, concentrating instead on cyclical factors. Yet R\&D expenditures are important determinants of innovation and technological progress and economic growth, and it would be surprising if R\&D was completely unaffected by macroeconomic policies. By incorporating into MULTIMOD recent empirical work on the relationship between R\&D spending and technological progress, we have been able to look at some of the consequences of liberating the supply side of the economy for the analysis of fiscal policy.

Our results indicate that endogenizing TFP magnifies the long-run effects of fiscal policies on the level of real GDP and stretches out the short- to medium-run effects on economic growth. In particular, we find that incorporating R\&D-induced innovation into the analysis more than doubles the long-run welfare losses associated with higher government spending or temporary tax cuts, and reduces real growth for a very long time. To put it somewhat differently, endogenizing $R \& D$ raises the long-run pain of adventurist fiscal policies without providing any extra gain. Furthermore, these costs spill over onto trading partners because lower levels of technological innovation in any one country hurt the rest of the world by lowering demand for its products and by reducing technological spillovers. Indeed, the welfare costs for the rest of the world also approximately double when R\&D is included in the model.

We take several lessons from this exercise. First, supply-side considerations can dramatically increase the costs of inappropriate policy actions, both in the short run and in the long run. Second, these increased costs are borne across the world, not simply in the country 
Table 4. Effects of a Temporary Tax Cut and Permanently Larger Government Debt in the United Kingdom

(Deviations from baseline as a percent of baseline, unless otherwise indicated.)

\begin{tabular}{|c|c|c|c|}
\hline GDP & Endogenous TFP & Exogenous TFP & Difference \\
\hline \multicolumn{4}{|l|}{ United Kingdom } \\
\hline Year 1 & 1.30 & 0.87 & 0.43 \\
\hline Year 5 & 1.05 & -0.13 & 1.18 \\
\hline Steady state & -0.71 & -0.14 & -0.56 \\
\hline Net present value ${ }^{1}$ & -11.14 & -6.78 & -4.36 \\
\hline \multicolumn{4}{|c|}{ Other industrial countries } \\
\hline Year 1 & 0.07 & 0.08 & -0.01 \\
\hline Year 5 & -0.07 & -0.02 & -0.05 \\
\hline Steady state & -0.13 & -0.07 & -0.06 \\
\hline Net present value $^{1}$ & -3.98 & -2.52 & -1.46 \\
\hline \multicolumn{4}{|l|}{ Private consumption } \\
\hline \multicolumn{4}{|l|}{ United Kingdom } \\
\hline Year 1 & 3.44 & 3.20 & 0.24 \\
\hline Year 5 & 3.46 & 2.69 & 0.77 \\
\hline Steady state & -1.29 & -0.70 & -0.60 \\
\hline Net present value ${ }^{1}$ & -12.79 & -7.71 & -5.08 \\
\hline \multicolumn{4}{|c|}{ Other industrial countries } \\
\hline Year 1 & 0.03 & 0.03 & -0.01 \\
\hline Year 5 & -0.11 & -0.07 & -0.04 \\
\hline Steady state & -0.11 & -0.03 & -0.08 \\
\hline Net present value ${ }^{1}$ & -3.49 & -1.61 & -1.87 \\
\hline
\end{tabular}

${ }^{1}$ The net present value for each variable assumes a discount rate of 4.2 percent and is expressed as a percent of the baseline value in the first year of the simulation. 
Figure 4: Effects of a Temporary Tax Cut and Permanently Larger Government Debt in the United Kingdom

Deviations from baseline as a percent of the baseline Mark III: Endogenous TFP - - Mark III: Exogenous TFP

Effects on Real GDP in the United Kingdom

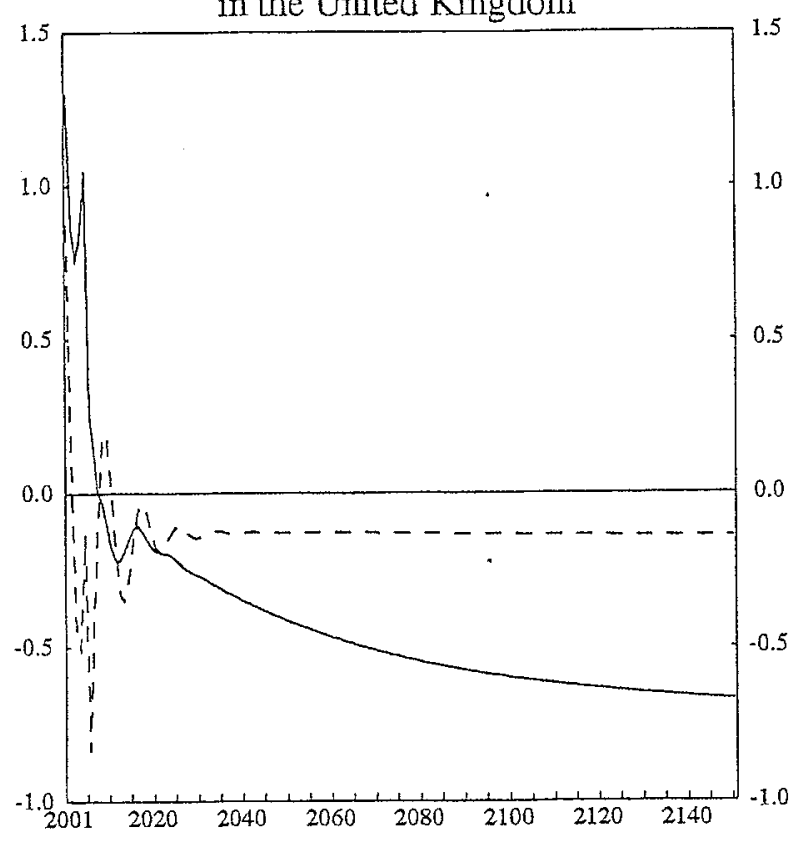

Effects on Private Consumption

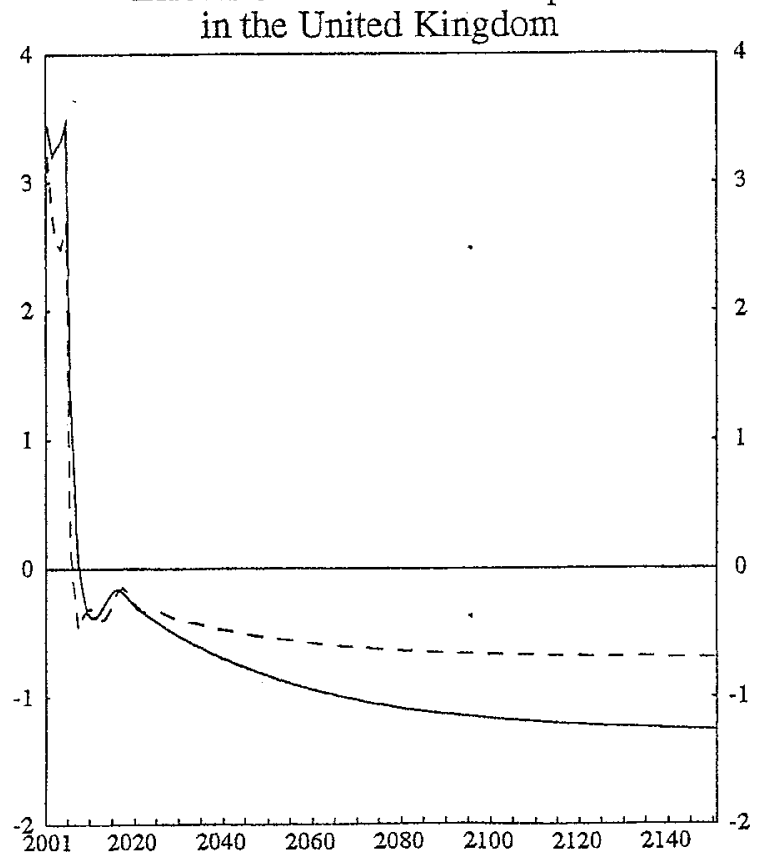

Effects on Real GDP

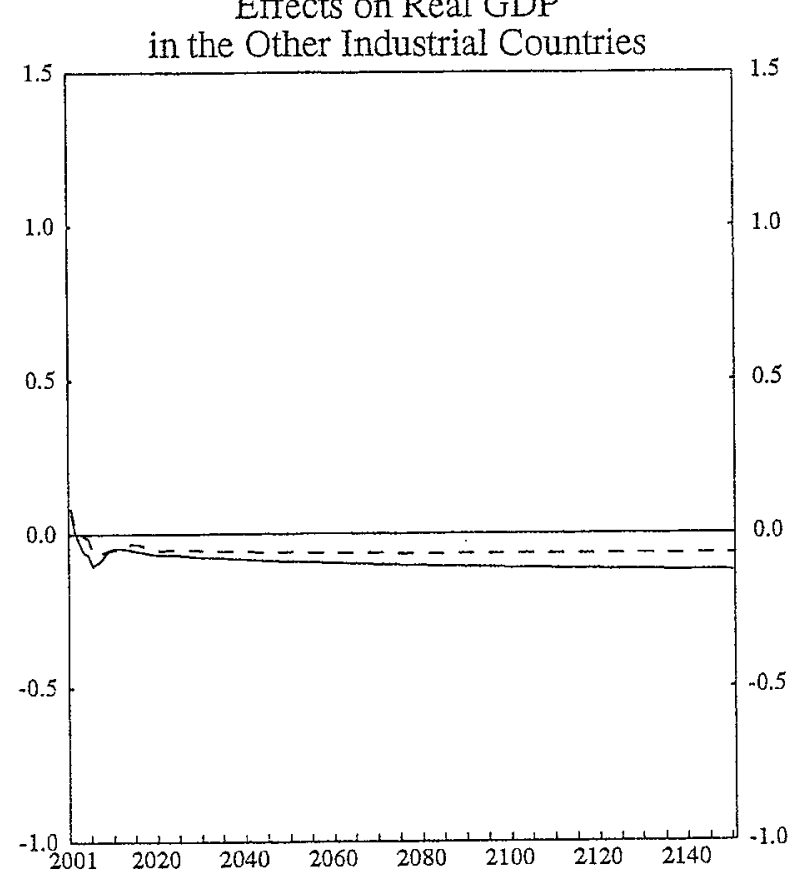

Effects on Private Consumption

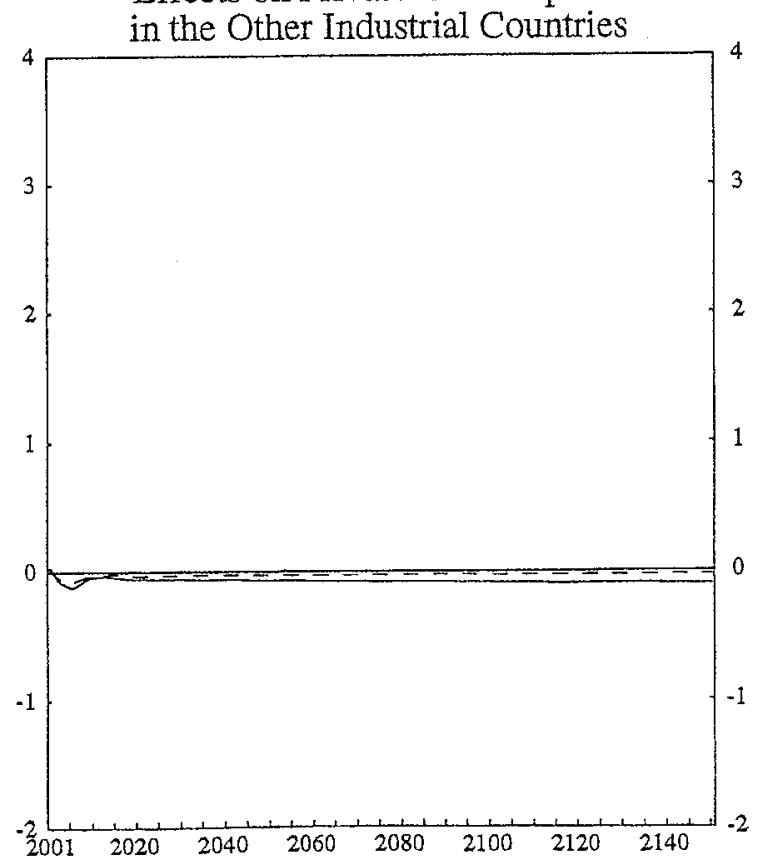


implementing the policies. The international nature of these supply-side costs strengthens the case for international cooperation and surveillance.

These results, of course, reflect the specification and parameters of the total factor productivity equation as well as the other simulation properties of MULTIMOD. Our specification focuses on technology and trade as the key determinants of total factor productivity, which is not to deny the importance of other factors such as investment in human capital or in infrastructure. As noted above, our elasticities of total factor productivity with respect to domestic and foreign $R \& D$ capital are broadly consistent with those found in the empirical literature. This literature is, however, relatively recent, and further research will undoubtably improve our understanding of the sizes of the parameter estimates used here and the mechanisms through which $R \& D$ and trade affect total factor productivity.

Our analysis has dealt only with the negative effects of fiscal policies that result in higher levels of government debt. For these types of simulations, the model is broadly linear, implying that the beneficial effects of lower levels of government debt would similarly be magnified in the R\&D-augmented version of the model.

This paper is, to the best of our knowledge, the first to analyze the impact of fiscal policies using a fully specified world econometric model incorporating key aspects of endogenous growth models (Helliwell, (1995). It extends the analysis of the effects on global growth of increased R\&D spending presented in Bayoumi, Coe, and Helpman (1998). We believe that this is a fertile area for future research. An important extension, for example, would be to fully endogenize R\&D expenditures as a function of its economic determinants. Notwithstanding their preliminary nature, our results suggest that the long-run effects of fiscal policies on economic growth may be much more important than previously thought when allowance is made for their impact on technological innovation. 


\section{SUMMARY OF MULTIMOD MARK III}

MULTIMOD is a dynamic, multicountry macro-economic model of the world economy that has been designed to study the transmission of shocks across countries, as well as the short- and medium-run consequences of alternative monetary and fiscal policies. It has several variants, the current versions of which are referred to as the Mark III generation. The core Mark III model includes explicit country submodels for each of the 7 largest industrial countries and an aggregate grouping of 14 smaller industrial countries. The remaining economies of the world are then aggregated into two separate blocks of developing and transition economies. Extended versions of MULTIMOD include separate submodels for many of the smaller industrial countries, and work has been initiated on expanding the analysis of the developing and transition economies.

The basic structure and properties of MULTIMOD are meant to represent wellestablished views about how modern industrial economies function and interact with each other. A consistent theoretical structure is employed for all industrial economies, and crosscountry differences in the behavior of agents (or the functioning of markets) are reflected in different estimated parameter values. The model converges to a balanced-growth path that is characterized by a full stock-flow equilibrium, in which debtor countries service the interest payments on their net foreign liabilities with positive trade balances.

The MULTIMOD modeling system includes a well-defined steady state analog model for each country and for the world economy as a whole. These steady state models serve two roles. First, they are used to construct terminal conditions for the dynamic models. Second, they can be used to study the long-run effects of shocks that have permanent consequences for, among others, saving, capital formation, output, real interest rates, and real exchange rates. The basic structure of MULTIMOD is simple enough that it is fairly straightforward to estimate additional country models for the smaller industrial economies.

Despite the focus on medium- and long-run properties, MULTIMOD also exhibits important short-run Keynesian dynamics that result from significant inertia in the inflation process. The Mark III generation features a nonlinear relationship between unemployment and inflation that reflects short-run capacity constraints and insider-outsider influences on wage setting. The asymmetric property of the Phillips curve provides a fundamental role for stabilization policies that is absent from linear models of the business cycle.

MULTIMOD assumes that behavior is completely forward looking in asset markets and partially forward looking in goods markets, but it is possible to study the effects of shocks under alternative assumptions about expectations formation and the degree of policy credibility. The model is solved with state-of-the-art simulation algorithms that have been designed specifically for such systems of equations.

Consumption-saving behavior is based on an extended Blanchard-Weil-Buiter paradigm in which agents are assumed to have finite planning horizons. The model has been extended to allow for realistic life-cycle income profiles and for the fact that a significant 
proportion of consumption is constrained by disposable income insofar as households are unable to borrow against future labor income streams.

Investment behavior is based on Tobin's $q$ theory, according to which the desired rate of investment exceeds the steady state rate as long as the expected marginal product of capital is greater than its replacement cost. The model allows for significant adjustment costs.

MULTIMOD has a standard specification of import and export behavior that embodies the notion that countries trade in diversified products. Import volumes are a function of the main components of aggregate demand, with import contents of the different components calibrated on the basis of information from input-output tables. Exports are modeled to approximately represent the mirror image of the foreign import demand functions.

Exchange rates and interest rates are related by an adjusted interest parity condition that can allow for persistent risk premiums. MULTIMOD provides a fundamental role for the real exchange rate, both in equilibrating aggregate demand and supply in the goods market and in ensuring that flow relationships are consistent with consumers' desired rates of asset accumulation. The short-run properties of the model to some extent mimic the properties of the Dornbusch overshooting model insofar as asset market prices are free to jump, while wages and other prices are characterized by stickier intrinsic and expectational dynamics.

The fiscal policy instruments include government absorption, distortionary capital taxes, and nondistortionary labor taxes (labor supply is exogenous). In the core version of MULTIMOD, government absorption is exogenous, and the aggregate tax rate is endogenized to ensure that the ratio of government debt to GDP converges to a target level. However, in the short run, it is possible to treat all three fiscal instruments as exogenous variables.

Given the forward-looking nature of MULTIMOD, the fundamental role of the monetary authorities is to provide an anchor for inflation expectations. This can be accomplished in many ways. Options available in the core version of Mark III include fixed exchange rates, money targeting, inflation targeting, and nominal income targeting.

MULTIMOD has not been designed to be a forecasting tool. The simulation baseline corresponds to the medium-term World Economic Outlook projections, which reflect the detailed knowledge and judgments of IMF country economists. These medium-term projections are then extended into a model-consistent, balanced-growth path, where the real interest rate is greater than the world real growth rate.

MULTIMOD is available to the public and can be obtained through e-mail to multimod@imf.org 


\section{References}

Aghion, Philippe, and Peter Howitt, 1992, "A Model of Growth Through Creative Destruction," Econometrica, Vol. 60, (March), pp. 323-51.

Bayoumi, Tamim, David T. Coe, and Elhanan Helpman, 1998, "R\&D Spillovers and Global Growth," Journal of International Economics (forthcoming).

Blanchard, Oliver J., 1985, "Debt, Deficits, and Finite Horizons," Journal of Political Economy, Vol. 93 (April), pp. 223-47.

Buiter, William H., 1988, "Death, Birth, Productivity Growth and Debt Neutrality," Economic Journal, Vol. 98 (June), pp. 279-93.

Cass, David, 1965, "Optimum Growth in an Aggregative Model of Capital Accumulation," Review of Economic Studies, Vol. 32 (July), pp. 233-40.

Coe, David T., and Elhanan Helpman, 1995, "International R\&D Spillovers," European Economic Review, Vol. 39 (May), pp. 859-87.

- and Alexander W. Hoffmaister, 1997, "North-South R\&D Spillovers," Economic Journal, Vol. 107 (January) pp. 134-139.

Eaton, Jonathan, and Samuel Kortum, 1996, “Trade in Ideas: Patenting and Productivity in the OECD," Journal of International Economics, Vol. 40 (May), pp. 251-78.

Ford, Robert, and Douglas Laxton, 1995, "World Public Debt and Real Interest Rates," IMF Working Paper 95/30 (Washington: International Monetary Fund).

Griliches, Zvi, 1988, "Productivity Puzzles and R\&D: Another Nonexplanation," Journal of Economic Perspectives, Vol. 2 (Fall), pp. 9-21.

Grossman, Gene M., and Elhanan Helpman, 1991, Innovation and Growth in the Global Economy (Cambridge, Massachusetts and London: MIT Press).

Helliwell, John F., 1995, "Modeling the Supply Side: What Are the Lessons from Recent Research on Growth and Globalization?" paper presented at meeting of Project Link, (South Africa).

International Monetary Fund, 1997, World Economic Outlook, October 1997: A Survey by the Staff of the International Monetary Fund, World Economic and Financial Surveys (Washington).

Juillard, Michel, and Douglas Laxton, 1996, "A Robust and Efficient Method for Solving Nonlinear Multicountry Rational Expectations Models," IMF Working Paper 96/106 (Washington: International Monetary Fund). 
— , Peter McAdam, and Hope Pioro, 1998, "An Algorithm Competition: First-Order Iterations Versus Newton-Based Techniques," Journal of Economic Dynamics and Control (forthcoming).

Keller, Wolfgang, 1998, “Are International R\&D Spillovers Trade-Related? Analyzing Spillovers Among Randomly Matched Trade Partners," European Economic Review (forthcoming).

Laxton, Douglas and others, 1998, MULTIMOD Mark III: The Core Dynamic and SteadyState Models, IMF Occasional Paper No. 164 (Washington: International Monetary Fund).

Lichtenberg, Frank R., and Bruno van Pottelsberghe de la Potterie, 1998, "International R\&D Spillovers: A Comment," European Economic Review (forthcoming).

Masson, Paul, Steven Symansky, and Guy Meredith, 1990, MULTIMOD Mark II: A Revised and Extended Model, IMF Occasional Paper No. 71 (Washington: International Monetary Fund).

McKibbin, Warwick J., and Jeffrey D. Sachs, 1991, Global Linkages: Macroeconomic Interdependence and Cooperation in the World Economy (Washington: Brookings Institution).

Mohnen, Pierre A., 1994, "The Econometric Approach to R\&D Externalities," Cahiers de Recherche du Département des Sciences Économiques de l'UQAM No. 9408 (Montreal: University of Quebec at Montreal).

Nadiri, M. Ishaq, 1993, "Innovations and Technological Spillovers," NBER Working Paper No. 4423 (Cambridge, Massachusetts: National Bureau of Economic Research).

Organization for Economic Cooperation and Development, 1995a, Basic Science and Technology Statistics (Paris: OECD).

Romer, Paul M., 1990, "Endogenous Technological Change," Journal of Political Economy, Vol. 98 (October), pp. S71-S102.

Solow, Robert M., 1956, "A Contribution to the Theory of Economic Growth," Quarterly Journal of Economics, Vol. 70 (February), pp. 65-94.

Tanzi, Vito, and Domenico Fanizza, 1995, "Fiscal Deficit and Public Debt in Industrial Countries, 1970-1994," IMF Working Paper 95/49 (Washington: International Monetary Fund).

Tobin, James, 1969, "A General Equilibrium Approach to Monetary Theory," Journal of Money, Credit and Banking, Vol. 1 (February), pp. 15-29. 
Weil, Philippe, 1989, “Overlapping Families of Infinitely-Lived Agents," Journal of Public Economics, Vol. 38 (March), pp. 183-98. 